\title{
Evaluation of the Acute Toxicity of an Ammonium Sulfate Fertilizer in Two Species of Anuran Tadpoles: Bufo mauritanicus (Schlegel 1841) and Rana ridibunda (Boulanger 1913)
}

\author{
Ayoub Naamane ${ }^{1 *}$, Sanaa Kamtass ${ }^{1}$, Soukaina Namoussi ${ }^{1}$, Nadia lounes ${ }^{1}$, \\ Abderrahmane Belhouari', Souad El Amrani' \\ 1 Laboratory of Ecology and Environment, Faculty of Sciences Ben M'Sik, Hassan II-University. Avenue Cdt Driss \\ El Harti, B.P.7955 Sidi Othmane, Casablanca, Morocco \\ * Corresponding author's e-mail: mr.naamane@gmail.com
}

\begin{abstract}
As part of the ecotoxicological tests on anuran tadpoles, the authors propose to study the sensitivity of different stages towards a nitrogenous compound frequently used in Morocco (Ammonium sulphate). For this purpose, the acute toxicity tests on tadpoles of two species (Bufo mauritanicus and Rana ridibunda) belonging to different stages of development were carried out. The lethal effects after 96 hours caused by the pollutant used as a reference (potassium dichromate) as well as ammonium sulfate increase with concentration and vary according to the stage of development. Significant differences were observed in the sensitivity of the tadpoles to pollutants according to the stage of development. The tadpoles belonging to the early stages of development (stage 24 according to Gosner, 1960) show greater acute effects on pollutants than the tadpoles belonging to the advanced stages of development (Stage 36 according to Gosner, 1960). After 96 hours, the lowest effective concentration (LOEC) is observed in the tadpoles belonging to the early stages of development (Stage 24 according to Gosner, 1960) in Rana ridibunda exposed just to the lowest concentration used $(20 \mathrm{mg} / \mathrm{l}$ of ammonium sulphate). Therefore, ammonium sulfate may play a role in the local decline of amphibians.
\end{abstract}

Keywords: anuran tadpoles, ecotoxicological tests, ammonium sulfate, Bufo mauritanicus, Rana ridibunda.

\section{INTRODUCTION}

One of the most serious global environmental problems is the loss of biological diversity. The human activities today threaten many species on the verge of global extinction (Díaz et al., 2020). Populations of several species have declined worldwide and amphibians are considered highly threatened (Grant et al., 2016, IUCN 2019, Bókony et al., 2020). Amphibians are vulnerable to environmental disturbance (Becker et al., 2010; Bovo et al., 2018; Ribeiro-Jr et al., 2018) due to their basic characteristics, such as their high skin permeability (Freitas et al., 2019) which offers limited activity capacity and increased vulnerability to the biological or chemical agents (Yan et al., 2008). Therefore, amphibians have been considered ideal bio indicators of the aquatic and agricultural ecosystems (Feng et al., 2004)._Their tadpoles are essential links to the various links in the food chain; they are both prey and predators (Junges et al., 2012); therefore, they play an important role in the freshwater and terrestrial ecosystems (Bókony et al., 2020)

It has been noted that the decline in amphibians is linked to the use of agrochemicals (Hayes et al., 2010; Polo-Cavia et al., 2016, Zhao et al., 2019). In Morocco, ammonium sulfate (a nitrogenous fertilizer which could possibly modify the biotic and abiotic environment) is the most used synthetic chemical in agricultural areas for soil fertilization. It should be noted that studies and diagnostics (PCN, 2016; Naamane et al., 2020) carried out point out the problem of fertilizer use in an empirical way, the theoretical needs do not match the volumes of fertilizers actually used, 
which could be a source of the surface water pollution due to run-off of these fertilizers and thus a threat to amphibians.

The studies conducted by Grant et al. (2016) in North America on 83 amphibian species (including anurans) revealed that the declines are not related to any particular threat on a continental scale but are the result of the locally induced processes. As a result, more emphasis needs to be placed on local solutions to this globally shared phenomenon. In Morocco, Bufo mauritanicus and Rana ridibunda are widespread and abundant species, living in various habitats, including agricultural sites. In this study, these anuran tadpoles are used for the first time as test animals in order to evaluate the toxic and lethal effects of ammonium sulfate in an aquatic environment. A short-term exposure assessment was carried out to evaluate the toxicity of this suspected threat (ammonium sulfate) in the tadpoles of Bufo mauritanicus and Rana ridibunda. The main objective was to assess the acute toxicity of ammonium sulfate at different concentrations, on different species of anuran tadpoles, belonging to different stages of development, in order to check whether mortality depends of the nature of the species, the concentration of the pollutant and the stage of development. This will allow us to provide reliable data regarding the effects of ammonium sulfate on local anuran species and standardize these tests later.

\section{MATERIALS AND METHODS}

\section{General presentation of the study area}

The swamp covered by this study is located in Tit Mellil (a village in the province of Médiouna in the Casablanca-Settat region (Morocco)). It is located at $33^{\circ} 3^{\prime} \mathrm{N}$ and $7^{\circ} 28^{\prime} \mathrm{W}$. It is an area without any sign of pollution, but to better characterize the water quality of this swamp, some of the physicochemical parameters were measured. The measurements were conducted at 4 points, $(2$ points on the banks: P1, P2 and 2 others in the center: P3, P4) on June 30, 2019. These 4 samples were chosen in order to have an overall picture of the swamp.

The choice of sampling of anuran tadpoles (Bufo mauritanicus and Rana ridibunda) on this swamp was guided in particular by its accessibility and for its good to excellent physical and chemical properties.

\section{Physicochemical parameters analyzed}

Concerning the physicochemical quality of the swamp water, the measurements of temperature, dissolved oxygen, $\mathrm{pH}$, conductivity and turbidity were carried out in situ using a Multi-parameter model MU61004. The analysis of the nitrogen compounds $\left(\mathrm{NO}_{3}{ }^{-}\right.$and $\left.\mathrm{NH}_{4}^{+}\right)$, phosphates $\left(\mathrm{PO}_{4}^{3-}\right)$, suspended matter ( $\left.\mathrm{SM}\right)$, and sulfates were carried out in the laboratory (Table 1) using the standard methods: AFNOR, and Rodier.

\section{Toxicity tests}

The tadpoles of Bufo mauritanicus and Rana ridibunda were captured with a strainer between April and July and driven to the laboratory. Upon arrival, they were placed in plastic basins containing $10 \mathrm{~L}$ of water (one tadpole/100 ml), and were fed with green salad ad libitum. After 7 days (acclimatization period), and based on the study carried out by Baran et al. (2013), the tadpoles were distributed in glass crystallizers $(\mathrm{V}=2 \mathrm{~L})$ containing $1 \mathrm{~L}$ of dechlorinated tap water at a rate of 10 tadpoles per crystallizer or 1 tadpole per $100 \mathrm{ml}$. The tadpoles were divided according to their developmental stages into 3 categories for Bufo mauritanicus and only into 2 categories for Rana ridibunda (because there is no tadpoles advanced development stage (development stage 36 (according to Gosner 1960)) in the swamp.

Table 1. Methods and parameters studied

\begin{tabular}{|l|l|}
\hline \multicolumn{1}{|c|}{ Parameters } & \multicolumn{1}{c|}{ Methods } \\
\hline Orthophosphates $\left(\mathrm{PO}_{4}{ }^{3-}\right)$ & $\begin{array}{l}\text { Spectrometric determination using ammonium molybdate } \\
\text { (AFNOR 2001). }\end{array}$ \\
\hline Ammonium $\left(\mathrm{NH}_{4}^{+}\right)$ & Indophenol blue spectrophotometric method (AFNOR 2001) \\
\hline Nitrate $\left(\mathrm{NO}^{3-}\right)$ & $\begin{array}{l}\text { Spectrometric determination using sodium salicylate (Rodier } \\
\text { 2009) }\end{array}$ \\
\hline Sulfate $\left(\mathrm{SO}_{4}{ }^{2-}\right)$ & Nephelometric method (AFNOR 2001) \\
\hline Suspended Matter (SM) & Filtration method (AFNOR 2001) \\
\hline
\end{tabular}


The first includes the tadpoles belonging to the early stages of development (stage 24 according to Gosner 1960), the tadpoles without internal gill limbs, with an average size of $0.94 \mathrm{~cm} \pm 0.05$ for Bufo mauritanicus and Rana ridibunda, the second includes the tadpoles belonging to the development stage 27 (according to Gosner 1960), the tadpoles with two legs (leg bud), of average size $1.81 \pm 0.11 \mathrm{~cm}$ for Bufo mauritanicus and $3.02 \pm 0.19 \mathrm{~cm}$ for Rana ridibunda, and the third includes the tadpoles belonging to development stage 36 (according to Gosner 1960), legs with toe paddles, with an average size of $2.47 \pm 0.08 \mathrm{~cm}$ for Bufo mauritanicus.

For carrying out the acute toxicity tests on the Anuran tadpoles having the same stage of development and coming from the same source, as recommended by USEPA (2002) and highlight a lethal effect following the daily exposure to dechlorinated water containing the pollutant and renewed every 24 hours. Standard pollutant, i.e. potassium dichromate $\left(\mathrm{K}_{2} \mathrm{Cr}_{2} \mathrm{O}_{7}\right)$ was used as a control, to which only the Bufo mauritanicus tadpoles were exposed. This pollutant is known for its particularly oxidizing nature. In addition, an agrochemical widely used in Morocco, ammonium sulfate $\left(\mathrm{NH}_{4}\right)_{2} \mathrm{SO}_{4}$ was employed, to which the tadpoles of two species (Bufo mauritanicus and Rana ridibunda) were exposed. For $96 \mathrm{~h}$, the tadpoles of different stages were subjected to 5 increasing concentrations of the pollutant, potassium dichromate and ammonium sulfate $(20,40$, $80,160,320 \mathrm{mg} / \mathrm{l})$. The concentrations selected are based on the previous studies conducted for ammonium nitrate. These concentrations were the maximum concentrations that should appear in water bodies after fertilizer run off applied in agricultural landscapes (Scholefield et al. 1996). For each concentration, and each stage of development, three identical tests were performed. The controls for each stage of development were planned to compare the sensitivity of different development stages to these agrochemicals and to provide more realistic data on the effects of ammonium sulfate on the local anuran species.

The crystallizers were placed under conditions of natural photoperiod, and constant aeration was ensured by bubblers. The physicochemical parameters (temperature, dissolved oxygen, $\mathrm{pH}$ and electrical conductivity) were measured daily using a Multi-parameter: analyzer model MU61004.
The dead individuals (no reaction to a slight push) were counted, removed from the crystallizers and stored in $10 \%$ formalin for further pathology study. Toxicity was assessed by visual observation of survival and expressed as a percentage.

\section{Data processing}

Microsoft office Excel 2007 software was used for data processing as well as a statistical method: analysis of variance test (ANOVA test) which was carried out using R version 3.6.1 software (2019-07-05) the objective of which is to check whether mortality depends of the nature of the species, the concentration and the stage of development. Another statistical method was used to determine LC 50 objectively by a nonlinear regression, using TRAP (The Toxicity Relationship Analysis Program) version 1.30 (June 25, 2015).

\section{RESULTS AND DISCUSSIONS}

\section{General assessment of the quality of swamp water}

By comparing the results the physicochemical parameters of the swamp waters with the values of the Moroccan surface water standard, we can consider that the quality of the swamp water is generally excellent.

\section{Eco-toxicological tests}

The physicochemical characteristics of the solutions recorded during the acute toxicity tests are grouped in Tables 2 and 3. The temperature and oxygen values appear relatively constant and identical to the controls; however, there is a correlation between the pollutant concentration and the conductivity and $\mathrm{pH}$ concentration. An increase in the concentration of the pollutant leads to an increase in conductivity and a decrease in $\mathrm{pH}$; this is due to dichromate for the crystallizers containing potassium dichromate and sulfates and ammonium ions for those with ammonium sulfates.

The results of acute toxicity tests obtained in tadpoles of two species, belonging to different developmental stages: early developmental stages, the tadpoles without limbs with internal gills (Stage 24); the tadpoles belonging to development stage 27, the two-legged tadpoles (leg bud), and finally the tadpoles belonging to development 
Table 2. Physicochemical characteristics of solutions during the acute toxicity tests for potassium dichromate

\begin{tabular}{|l|c|c|c|c|c|c|}
\hline \multirow{2}{*}{ Measured parameters } & \multirow{2}{*}{ Witnesses } & \multicolumn{5}{|c|}{ Concentrations of potassium dichromate } \\
\cline { 3 - 7 } & & $20 \mathrm{mg} / \mathrm{l}$ & $40 \mathrm{mg} / \mathrm{l}$ & $80 \mathrm{mg} / \mathrm{l}$ & $160 \mathrm{mg} / \mathrm{l}$ & $320 \mathrm{mg} / \mathrm{l}$ \\
\hline Temperature. ${ }^{\circ} \mathrm{C}$ & $21.6 \pm 0.3$ & $21.6 \pm 0.3$ & $21.6 \pm 0.3$ & $21.6 \pm 0.3$ & $21.6 \pm 0.3$ & $21.6 \pm 0.3$ \\
\hline $\mathrm{pH}$ & $8.28 \pm 0.2$ & $8.28 \pm 0.2$ & $8.25 \pm 03$ & $8.14 \pm 0.3$ & $7.42 \pm 0.3$ & $6.54 \pm 0.3$ \\
\hline Conductivity $(\mu \mathrm{s} / \mathrm{l})$ & $1.68 \pm 0.2$ & $1.74 \pm 0.2$ & $1.77 \pm 0.2$ & $1.84 \pm 0.2$ & $1.96 \pm 0.2$ & $2.04 \pm 0.2$ \\
\hline $\begin{array}{l}\text { Dissolved oxygen } \\
(\mathrm{mg} / \mathrm{l})\end{array}$ & $9 \pm 0.2$ & $9 \pm 0.2$ & $9 \pm 0.2$ & $9 \pm 0.2$ & $9 \pm 0.2$ & $9 \pm 0.2$ \\
\hline
\end{tabular}

Table 3. Physicochemical characteristics of solutions during the acute toxicity tests for ammonium sulfates

\begin{tabular}{|l|c|c|c|c|c|c|}
\hline \multirow{2}{*}{ Measured parameters } & \multirow{2}{*}{ Witnesses } & \multicolumn{5}{|c|}{ Concentrations of potassium dichromate } \\
\cline { 3 - 7 } & & $20 \mathrm{mg} / \mathrm{l}$ & $40 \mathrm{mg} / \mathrm{l}$ & $80 \mathrm{mg} / \mathrm{l}$ & $160 \mathrm{mg} / \mathrm{l}$ & $320 \mathrm{mg} / \mathrm{l}$ \\
\hline Temperature, ${ }^{\circ} \mathrm{C}$ & $20.6 \pm 0.3$ & $20.6 \pm 0.3$ & $20.6 \pm 0.3$ & $20.6 \pm 0.3$ & $20.6 \pm 0.3$ & $20.6 \pm 0.3$ \\
\hline $\mathrm{pH}$ & $8.28 \pm 0.2$ & $8.28 \pm 0.2$ & $8.25 \pm 03$ & $8.22 \pm 0.3$ & $8.15 \pm 0.3$ & $7.42 \pm 0.3$ \\
\hline Conductivity $(\mu \mathrm{s} / \mathrm{l})$ & $1.68 \pm 0.2$ & $1.74 \pm 0.2$ & $1.78 \pm 0.2$ & $1.81 \pm 0.2$ & $1.95 \pm 0.2$ & $2.3 \pm 0.2$ \\
\hline $\begin{array}{l}\text { Dissolved oxygen } \\
(\mathrm{mg} / \mathrm{l})\end{array}$ & $9 \pm 0.2$ & $9 \pm 0.2$ & $9 \pm 0.2$ & $9 \pm 0.2$ & $9 \pm 0.2$ & $9 \pm 0.2$ \\
\hline
\end{tabular}

stage 36, the two-legged stage (leg with toe paddle) reveals a significant difference in sensitivity between these different development stages as well as the concentrations (Table 4 and 5). The stages of development that showed a significant difference are stages 24 and 36 and concerning the concentrations are $0,20,40,160$ and $360 \mathrm{mg} / 1$ of pollutant. It was noted that no mortality was observed during the experimental period for the control groups.

For the exposure duration of $96 \mathrm{~h}$, there was no mortality in the Bufo mauritanicus tadpoles exposed to the low concentration $(20 \mathrm{mg} / \mathrm{l}$ of ammonium sulfates) and which belong to different development stages (Fig. 1). On the other hand, the same concentration of ammonium sulfates resulted in a mortality of $10 \%$ in the Rana ridibunda species (Fig. 2) for the early stage of development (stage 24), which indicates that it may be less tolerant to sulfates than Bufo mauritanicus and this could explain its low abundance in the swamp.

Concerning the tadpoles of Bufo maritanicus exposed to ammonium sulfate, the concentration of the pollutant: $40 \mathrm{mg} / \mathrm{l}$ has no observed effect (NOEC) for the both stages of development (24 and 27) whereas, for stage of development 36 , NOEC is noted at $160 \mathrm{mg} / 1$ (Fig. 1). Indeed, during this no-observed-effect concentration, the tadpoles were all alive and seemed to be feeding normally. This resistance may be due to more effective detoxification mechanisms than those in the early development stages (Bucciarelli et al. 1999).

The authors observed the lethal effects caused by ammonium sulfate that increase with stage of development and the concentrations (Fig. 3 and 4). For the Bufo mauritanicus tadpoles exposed to ammonium sulfate, the lowest effective concentration (LOEC) is $80 \mathrm{mg} / \mathrm{l}$ for developmental stages 24 and 27 while it increases to the concentration of $320 \mathrm{mg} / 1$ for developmental stage 36 .

For Rana ridibunda, the lowest effective concentration (LOEC) is the concentration $20 \mathrm{mg} / \mathrm{l}$ of ammonium sulfate to which the tadpoles in development stage 24 were exposed to and it changes to the concentration of $80 \mathrm{mg} / \mathrm{l}$ for development

Table 4. ANOVA test to check whether the morality varies according to the type of species, the stages of development and or the concentrations

\begin{tabular}{|c|c|c|c|c|c|c|}
\hline Specification & $\begin{array}{c}\text { SS } \\
\text { (Sum-of-squares) }\end{array}$ & $\begin{array}{c}\mathrm{df} \\
\text { (Degrees of } \\
\text { freedom) }\end{array}$ & $\begin{array}{c}\text { MS } \\
\text { (Mean squares) }\end{array}$ & F value & $\operatorname{Pr}(>F)$ & \\
\hline Species & 0.0596 & 1 & 0.0596 & 1.9293 & 0.1671 & \\
\hline Pollutants & 0.0334 & 1 & 0.0334 & 1.082 & 0.3001 & \\
\hline Stages & 1.9290 & 2 & 0.9645 & 31.2215 & $7.399 \mathrm{e}-12$ & *** \\
\hline Concentrations & 18.4678 & 5 & 3.6936 & 119.5617 & $<2.2 \mathrm{e}-16$ & *** \\
\hline Residuals & 4.1396 & 134 & 0.0309 & & & \\
\hline
\end{tabular}


Table 5._ANOVA test inside the different variables (Species, stages, and concentrations)

\begin{tabular}{|c|c|c|c|c|c|}
\hline T test & Estimate & Std. Error & $\mathrm{t}$ value & $\operatorname{Pr}(>|t|)$ & \\
\hline (Intercept) & 0.315509 & 0.019832 & 15.9091 & $<2 \mathrm{e}^{-16}$ & *** \\
\hline Specie - Bufo mauritanicus & -0.027546 & 0.019832 & -1.3890 & 0.16714 & \\
\hline Specie - Rana ridibunda & 0.027546 & 0.019832 & 1.3890 & 0.16714 & \\
\hline Pollutant - potassium dichromate & 0.017593 & 0.016913 & 1.0402 & 0.30012 & \\
\hline Pollutant - ammonium sulfate & -0.017593 & 0.016913 & -1.0402 & 0.30012 & \\
\hline Stage - S 24 & 0.162500 & 0.020714 & 7.8450 & $<2 \mathrm{e}^{-16}$ & *** \\
\hline Stage - S 27 & -0.035648 & 0.020714 & -1.7210 & 0.08756 & . \\
\hline Stage - S 36 & -0.126852 & 0.023918 & -5.3035 & $<2 \mathrm{e}^{-16}$ & *** \\
\hline Concentration - C 0 & -0.313194 & 0.032751 & -9.5628 & $<2 \mathrm{e}^{-16}$ & *** \\
\hline Concentration - C 160 & 0.290972 & 0.032751 & 8.8842 & $<2 \mathrm{e}^{-16}$ & *** \\
\hline Concentration - C 20 & -0.300694 & 0.032751 & -9.1811 & $<2 \mathrm{e}^{-16}$ & *** \\
\hline Concentration - C 320 & 0.645139 & 0.032751 & 19.6980 & $<2 \mathrm{e}^{-16}$ & *** \\
\hline Concentration - C 40 & -0.279861 & 0.032751 & -8.5450 & $<2 \mathrm{e}^{-16}$ & *** \\
\hline Concentration - C 80 & -0.042361 & 0.032751 & -1.2934 & 0.19809 & \\
\hline
\end{tabular}

stage 27 (Fig. 2). A decrease in locomotors and food intake performance was also observed in the tadpoles exposed to pollutants compared to controls. The decrease in food intake may be due to a loss of activity or energy investment in the detoxification mechanisms (Schmuck et al. 1994). When animals are exposed to adverse conditions, they exhibit the escape behaviors or activate physiological adjustments in an attempt to stabilize the body (Salla et al. 2015). Energy stores, glycogen and, to a lesser extent, protein can be depleted in response to exposure of amphibians to environmental contaminants, when the body tries to maintain homeostasis by compensatory metabolic mechanisms, thus using energy reserves (Dornelles et Oliveira 2014). Moreover, chemical pollutants are capable of even causing deregulation of the endocrine system and thus affecting the hormonal activity. Wild leopard frogs
(Rana pipiens) exposed to a chemical exhibited developmental delay and hermaphroditism (Hayes et al., 2002).

Exposure to an agrochemical (ammonium nitrate) has already been shown to reduce the activity or feeding rate of various amphibian larvae (Burgett et al., 2007). Several mechanisms have been suggested to explain the toxicity of ammonia (Marco and Ortiz-Santaliestra, 2009). Exposing tadpoles to moderate levels of ammonia can reverse the ammonia diffusion gradient, and animals can absorb ammonia from the water. In these cases, the costly urea synthesis becomes a common mechanism for detoxifying ammonia (Wright and Wright, 1996). This additional energy investment therefore alters the swimming activity. We also know that the ammonium ion affects the nervous system of many vertebrates by replacing the potassium cations in the nervous membranes

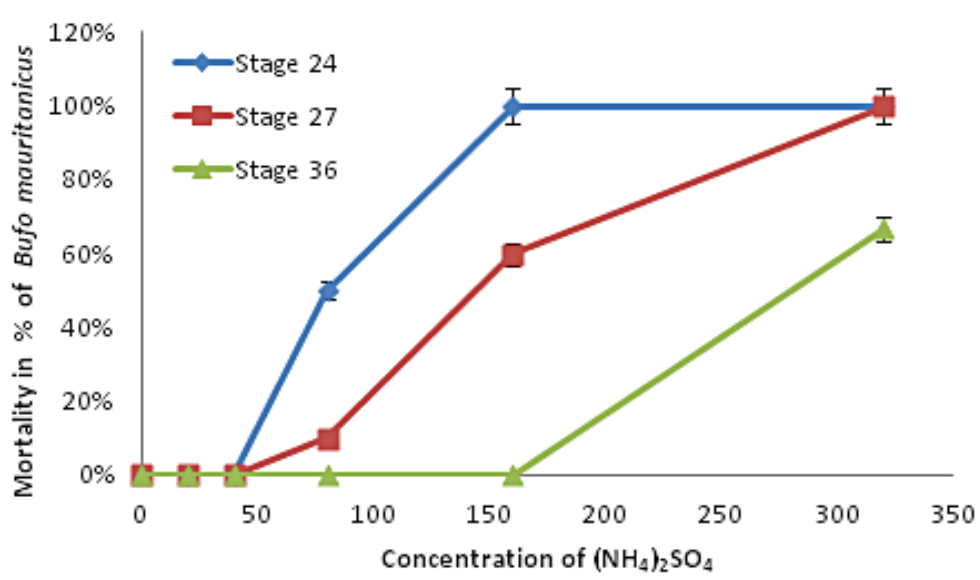

Fig. 1. Mortalities recorded in the acute toxicity test in the Bufo mauritanicus tadpoles at the development stage 24, 27 and 36 exposed to ammonium sulfate $\left(\left(\mathrm{NH}_{4}\right)_{2} \mathrm{SO}_{4}\right)$ for 96 hours 


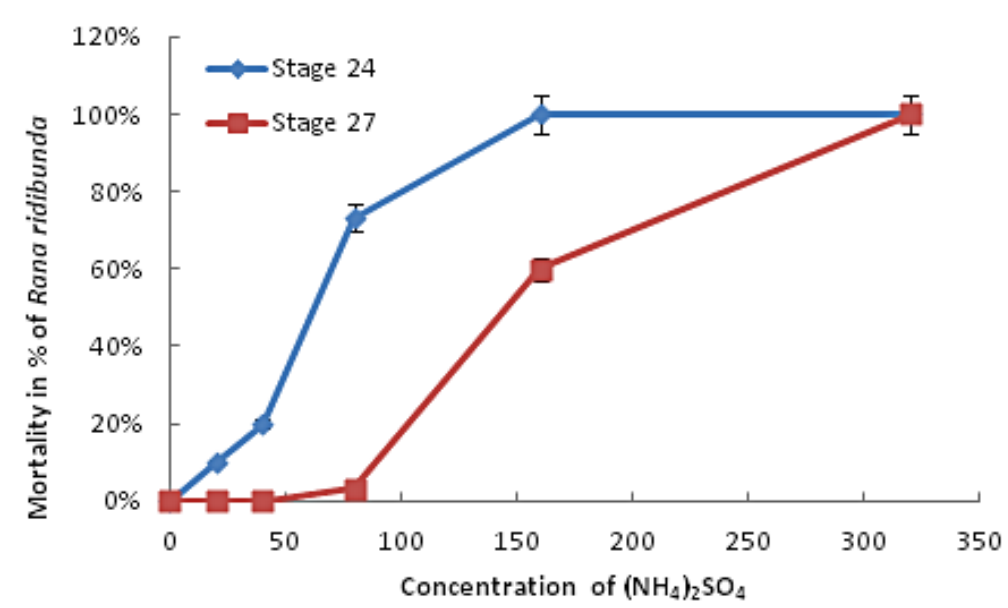

Fig. 2. Mortalities recorded in the acute toxicity test in the Rana ridibunda tadpoles at the stage 24 and 27 exposed to ammonium sulfate $\left(\left(\mathrm{NH}_{4}\right)_{2} \mathrm{SO}_{4}\right)$ for 96 hours

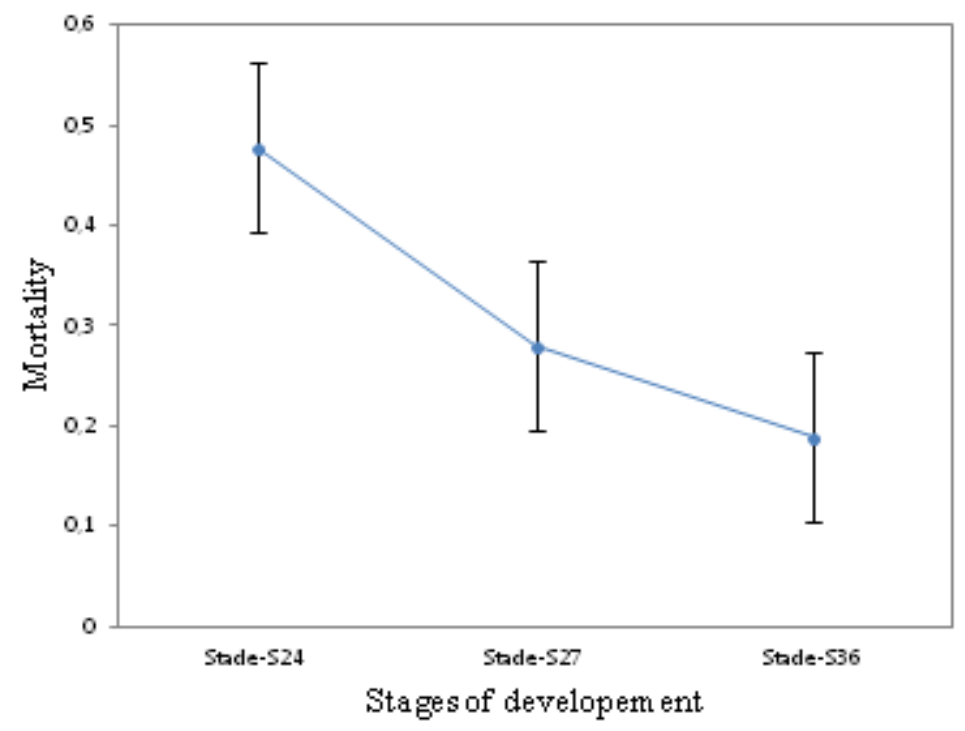

Fig. 3. Graphical ANOVA for mortality according to the stage of development

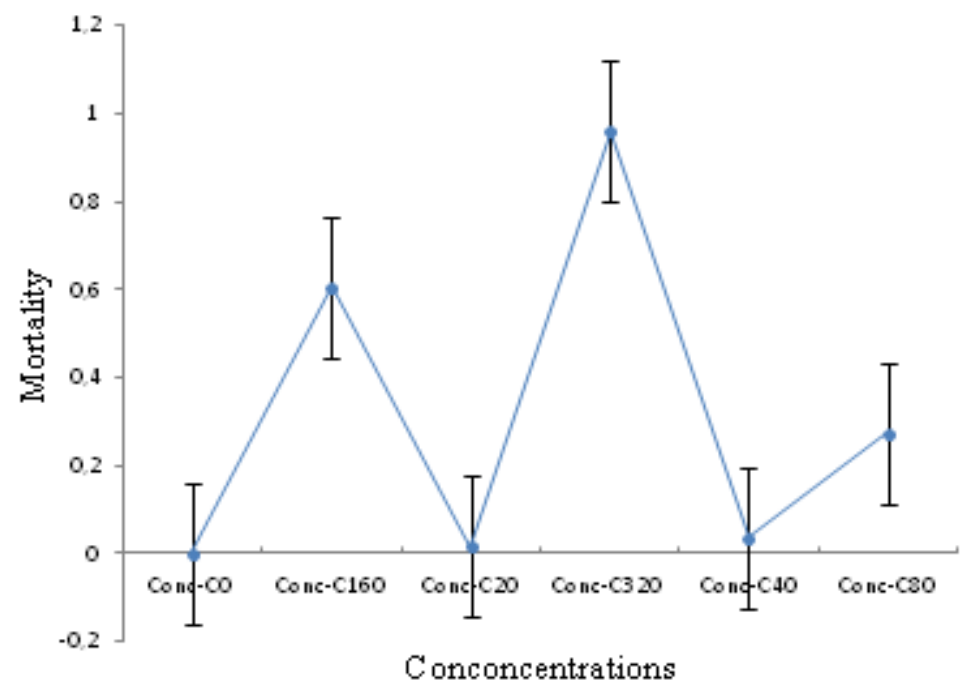

Fig. 4. Graphical ANOVA for mortality according to concentration 
(Randall et Tsui, 2002). In fish, this mechanism causes dysfunction of Mauthner's cells (giant neurons involved in rapid reflex responses), which ultimately causes an increase in latency preventing the escape from predators (McKenzie et al., 2009). In addition, the replacement of potassium by ammonium at the sarcolemmal membrane can cause depolarization of the white muscle (McKenzie et al., 2009), which includes most of the axial musculature and is responsible for performing the rapid movements involved in the escape response in fish (Sherkov, 1970).

The main behaviors of tadpoles are feeding and avoiding predators (Denver, 2019). However after the exposure of the Bufo mauritanicus and Rana ridibunda tadpoles to ammonium sulfate, they may be more susceptible to predation in addition to poor foraging. In addition, more physiological studies are needed to identify the mechanisms involved in the exposure to ammonium sulfate in tadpoles.

The same observation can be noted for the lethal concentration which affects $50 \%$ of the population (LC50). It increases with the stage of development and varies slightly between the two species (Table 6). We can also note significant lethal effects (100\% mortality), Bufo mauritanicus tadpoles exposed to ammonium sulfate (Fig. 1) showed $100 \%$ mortality from concentration of $160 \mathrm{mg} / \mathrm{l}$ for the early development stage (Stage24), and it is the same for Rana ridibunda (Fig. 2). The stage 27 has $100 \%$ mortality from the concentration of $320 \mathrm{mg} / \mathrm{l}$ ammonium sulfate for both species (Rana ridibunda and Bufo mauritanicus) and recently stage 36 which seems to be the most tolerant shows a fair mortality of $67 \%$ at the maximum tested concentration of $320 \mathrm{mg} / \mathrm{l}$ ammonium sulfate for Bufo mauritanicus. This high sensitivity is due to incomplete differentiation of tissues and organs in tadpoles in the early stages of development (Herkovits et al. 1978). Since the development of anurans is characterized by the appearance of new phenotypic characters over time (Fabrezi et al., 2019). In addition, in the anurans tadpoles belonging to the advanced stage of development, the gills are internal but for the first stages of development, the gills are external and in direct contact with water (Gosner, 1969); therefore, during this stage of development, a negative effect of ammonium sulfates on osmoregulation could be significant.

The tolerance of tadpoles to toxic substances increases with their stage of development, and this has also been reported in previous studies (Ortiz-Santaliestra, 2006) in which tadpoles were exposed to chemicals.

In addition, the differences in tolerance between the species of anurans are also remarkable and agree with the studies carried out by GarcíaMuñoz et al. (2011) including 4 species of anurans (Bufo bufo, Bufo calamita (Epidalea calamita), Pelodytes ibericus and Pelophylax perezi) were exposed to a fertilizer (ammonium nitrate) at numerous concentrations. The tolerance of tadpoles to toxic substances is seen to increase with their stage of development, and this has also been reported in previous studies. Mann et al. (2009) in his study reported that nitrates are often without any effect on different species of anurans (Gosner stage 25) at concentrations up to $100 \mathrm{mg} / \mathrm{l}$. Additionally, Miaud et al. (2011) showed that calamite toad tadpoles (Gosner stage 25) are highly resistant to the nitrate exposure for an exposure time of $72 \mathrm{~h}$ at $1 \mathrm{~g} / 1$ (no mortality). This resistance was also observed for the tadpoles in the early stages of development (stages 10-12) exposed to $200 \mathrm{mg} / \mathrm{l}$ for 15 days (Ortiz et al. 2004). In this study, the exposure to ammonium sulfate

Table 6. Estimate of lethal concentration that affects $50 \%$ of the population (LC 50) for the 2 species

\begin{tabular}{|c|c|c|c|c|c|c|}
\hline Species & Pollutant & $\begin{array}{l}\text { Development } \\
\text { stage }\end{array}$ & LC $50(\mathrm{mg} / \mathrm{l})$ & $\begin{array}{l}\text { 95\% LCL (The } \\
\text { lower control limit ) }\end{array}$ & $\begin{array}{l}\text { 95\%UCL (The } \\
\text { upper control limit ) }\end{array}$ & $\begin{array}{l}\text { Standard } \\
\text { error }\end{array}$ \\
\hline \multirow{6}{*}{ Bufo mauritanicus } & \multirow{3}{*}{$\left(\mathrm{NH}_{4}\right)_{2} \mathrm{SO}_{4}$} & Stage 24 & 80.00 & 80.00 & 80.00 & 0.00 \\
\hline & & Stage 27 & 147.23 & 145.78 & 148.67 & 0.45349 \\
\hline & & Stage 36 & 294.73 & 294.73 & 294.73 & 0.00 \\
\hline & \multirow{3}{*}{$\mathrm{K}_{2} \mathrm{Cr}_{2} \mathrm{O}_{7}$} & Stage 24 & 71.322 & 60.502 & 82.14 & 3.39 \\
\hline & & Stage 27 & 173.09 & 168.37 & 177.81 & 1.48 \\
\hline & & Stage 36 & 188.52 & 188.52 & 188.52 & 0.00 \\
\hline \multirow{2}{*}{ Rana ridibunda } & \multirow{2}{*}{$\left(\mathrm{NH}_{4}\right)_{2} \mathrm{SO}_{4}$} & Stage 24 & 68.071 & 67.615 & 68.52 & 0.14 \\
\hline & & Stage 27 & 151.02 & 148.37 & 153.66 & 0.83 \\
\hline
\end{tabular}


had a lethal effect demonstrated by the increased mortality of the exposed tadpoles. This reveals that it can be seriously dangerous for the survival of anurans. The results reveal that anurans are very sensitive to the negative effects of ammonium sulfate which is in agreement with the studies carried out by Sparling et al. (2010); Hayes et al., (2010); Hoffmann (2010); Polo-Cavia et al. (2016) who have already mentioned the negative effects of agrochemicals on the anuran tadpoles. In addition, the earlier the development stage is, the greater the vulnerability of the tadpoles to the pollutant, which also strengthens the previous studies (Castañaga et al., 2009; Aronzon et al., 2011). This demonstrates the need to use the early stages of development when assessing the effects of one or more chemicals, such as ammonium sulfate, on the tadpoles of anurans.

In addition, the studies by Ortiz-Santaliestra et al. (2012) showed that the mortality of the Salamandra salamandra tadpoles related to ammonium nitrate was five times higher at high than at low density. Overcrowding (group effect) can lead to strong trophic competitiveness within the species. Some more vigorous tadpoles then monopolize food to the detriment of the community to finally metamorphose. The release of growth inhibitors by the most developed tadpoles in water with feces is also envisaged, and these proteinaceous substances would be absorbed by the smallest tadpoles (Hourdry et al., 1985). Thus, the tadpoles of anurans living in temporary ponds are possibly more impacted by chemicals than those living in permanent ponds.

Ultimately, these results suggest that the decline in the population of anurans could be caused by contamination by ammonium sulfate in their aquatic environment with a dependence of the mortality on the concentration of the pollutant, the stage of development and probably the nature of the species. On the other hand, the effects of ammonium sulfate measured in the laboratory on the tadpoles of the two species of anurans may be different from the stress experienced in the field as a result of synergistic effects with other environmental factors. Variations in the abiotic and biotic factors as well as different ecological conditions can act in complex ways to influence the morphology, behavior, growth and development of tadpoles (Denver, 2019). Finally, more research efforts are therefore needed to improve our knowledge of how ammonium sulfate can impact the decline of the amphibian population.

\section{CONCLUSION}

At the end of this work, which aimed to assess the toxicity of ammonium sulfate in the anuran tadpoles, the results reveal that the pollution by ammonium sulfate from anthropogenic sources such as agriculture, entering surface waters by runoff, has acute toxicological effects in anurans. The presence of ammonium sulfate has a negative impact since it modifies the way in which the tadpoles interact with their environment, which results in a drastic reduction in the number of survivors.

Furthermore, this sensitivity varies according to the stage of development, the concentrations and slightly with the species. Significant differences between the different stages of development as well as the concentrations studied were noted. The higher the exposure concentration, the more the resistance to the pollutant decreases; however, it was noted that the stage of development has a decisive influence on the sensitivity of species. The earlier the stage of development, the more the nuisance of the pollutant or the fragility of the tadpoles increases. Therefore, the results make it possible to deduce that the ammonium sulphate has an impact on the survival of tadpoles and this impact depends on various factors.

The contamination of surface water with ammonium sulfate, may therefore play a role in the decline of the local amphibian population; however, additional studies on the toxicity of ammonium sulfate in anurans, its ecological implications, as well as measurements of sulfate and ammonium concentrations in the areas close to agricultural activities which allows to have relevant concentrations of this pollutant for the environment, are recommended in order to subsequently implement a local conservation action plan to combat the worldwide decline in the amphibian populations.

\section{REFERENCES}

1. Aronzon, C.M., Sandoval, M.T., Herkovits, J. \& Pérez Coll, C.S. 2011. Stage-dependent susceptibility to copper in Rhinella arenarum embryos and larvae. Environ. Toxicol. Chem. 30, 2771-2777.

2. Baran N., Amalric L., Saplairoles M. et al. 2013. Evaluation in situ de l'impact des produits phytosanitaires sur les eaux souterraines et les écosystèmes associés de la plaine alluviale de l'Ariège: rapport année 1 du projet ELISE. Rapport final. BRGM/ 
RP-62056-FR, 58p., 43 ill.

3. Becker, C.G., Fonseca, C.R., Haddad, C.F.B., Prado, P.I. 2010. Habitat split as a cause of local population declines of amphibians with aquatic larvae. Conserv. Biol. 24, 287-294.

4. Bókony, V., Verebélyi, V., Ujhegyi, et al. 2020. Effects of two little-studied environmental pollutants on early development in anurans. Environmental Pollution, 114078.

5. Bovo, A.A.A., Magioli,M., Percequillo, A.R. et al. 2018. Human-modified landscape acts as refuge for mammals in Atlantic forest. Biota Neotropica 18 (2), e20170395.

6. Bucciarelli T, Sacchetta P, Pennelli A. et al. 1999. Characterization of toad glutathione transferase. Biochim Biophys Acta 1431:189-198.

7. Burgett, A.A., Wright, C.D., Smith, G.R., et al. 2007. Impact of ammonium nitrate on wood frog (Rana sylvatica) tadpoles: effects on survivorship and behavior. Herpetol. Conserv. Biol. 2, 29-34

8. Castañaga, L.A., Asorey, C.M., Sandoval, M.T., et al. 2009. Stage-dependent teratogenic and lethal effects exerted by ultraviolet $B$ radiation on Rhinella (Bufo)arenarum embryos. Environ. Toxicol. Chem. 28, 427-433.

9. Denver R.J. 2019. Tadpole Behavior and Metamorphosis. Encyclopedia of Animal Behavior, 2010, Pages 375-378

10. Díaz, S., Settele, J., Brondízio, E., et al. 2020. Summary for policymakers of the global assessment report on biodiversity and ecosystem services of the Intergovernmental Science-Policy Platform on Biodiversity and Ecosystem Services.

11. Dornelles, M. F. \& Oliveira, G. T. 2014. Effect of atrazine, glyphosate and quinclorac on biochemical parameters, lipid peroxidation and survival in bullfrog tadpoles (Lithobates catesbeianus). Archives of Environmental Contamination and Toxicology 66, 415-429.

12. USEPA. 2002. United states. Environmental Protection Agency Methods for Measuring the Acute Toxicity of Effluents and Receiving Waters to Freshwater and Marine Organisms. Fifth Edition. EPA-821-R-02-012

13. García-Muñoz, E., Guerrero, F., Bicho, R. C., \& Parra, G. 2011. Effects of ammonium nitrate on larval survival and growth of four Iberian amphibians. Bulletin of environmental contamination and toxicology, 87(1), 16-20.

14. Fabrezi, M., Lozano, V.L., \& Cruz, J.C. 2019. Differences in responsiveness and sensitivity to exogenous disruptors of the thyroid gland in three anuran species. Journal of Experimental Zoology Part B: Molecular and Developmental Evolution, 332(7), 279-293.
15. Feng, S., Kong, Z., Wang, X. et al. 2004. Acute toxicity and genotoxicity of two novel pesticides on amphibian, Rana N. Hallowell. Chemosphere 56, 457-463.

16. Freitas, J.S., Kupsco, A., Diamante, G. et al. 2016. Influence of temperature on the thyroidogenic effects of diuron and its metabolite 3,4-DCA in tadpoles of the American bullfrog (Lithobates catesbeianus). Environ. Sci. Technol. 23, 13095-13104.

17. Freitas, J. S., Girotto, L., Goulart, B. V. et al. 2019. Effects of 2, 4-D-based herbicide (DMA ${ }^{\circledR} 806$ ) on sensitivity, respiration rates, energy reserves and behavior of tadpoles. Ecotoxicology and environmental safety, 182, 109446.

18. Gosner, K.L. 1960. A simplified table for staging anuran embryos and larvae with notes on identification. Herpetologica. 16, 183-190.

19. Grant, E.H., Miller, D.A., Schmidt, B.R., et al. 2016. Quantitative evidence for the effects of multiple drivers on continental- scale amphibian declines. Sci. Rep. 6, 25625.

20. Hayes, T., Haston, K., Tsui, M. et al. 2002. Feminization of male frogs in the wild. Nature, 419, 895-896.

21. Hayes, T.B., Falso, P., Gallipeau, S., Stice, M. 2010. The cause of global amphibian declines: a developmental endocrinologist's perspective. J. Exp. Biol. 213, 921-933.

22. Herkovits J, Fernandez A. 1978. Tolerancia a noxas durante el desarrollo embrionario. Medicina (Buenos Aires) 39, 400-408.

23. Hourdry J., Beaumont A., 1985. The metamorphoses of amphibians. Fondation singer polignac. In les métamophoses des amphibiens par Hourdry et al., 1985.

24. IUCN, 2019. Red list of threatened species. https:// www.iucnredlist.org (accessed 17 december 2019).

25. Junges, C., Peltzer, P., Lajmanovich, R. et al. 2012. Toxicity of the fungicide trifloxystrobin on tadpoles and its effect on fish-tadpole interaction. Chemosphere 87, 1348-1354.

26. Mann R.M., Hyne R.V. et al. 2009. Amphibians and agricultural chemicals: review of the risks in a complex environment. Environ Pollut 157(11), 2903-2927.

27. Marco, A., Ortiz-Santaliestra, M.E. 2009. Pollution: impact of reactive nitrogen on amphibians. In: Heatwole, H., Wilkinson, J.W. (Eds.), Amphibian Biology, Vol. 8, Amphibian Decline: Diseases, Parasites, Maladies and Pollution. Surrey Beatty \& Sons, Baulkham Hills, Australia, pp. 3145-3185.

28. McKenzie, D.J., Shingles, A., Claireaux, G., Domenici, P. 2009. Sublethal concentrations of ammonia impair performance of the Teleost fast-start escape response. Physiol. Biochem. Zool. 82, 353-362. 
29. Miaud, C., Oromí, N., Navarro, S., Sanuy, D., 2011. Intra-specific variation in nitratetolerance in tadpoles of the Natterjack toad. Ecotoxicology 20, 1176-1183.

30. Naamane, A., Sadiq, A., Belhouari, A., Iounes, N., \& El Amrani, S. 2020. Enquête sur l'utilisation des engrais et pesticides chez les agriculteurs de la région de Casablanca-Settat. Revue Marocaine des Sciences Agronomiques et Vétérinaires, 8(3). (in French)

31. Ortiz, M.E., Marco, A., Saiz, N., \& Lizana, M. 2004. Impact of ammonium nitrate on growth and survival of six European amphibians. Archives of Environmental Contamination and Toxicology, 47(2), 234-239.

32. Ortiz-Santaliestra, M.E., Marco, A., Fernández, M.J., \& Lizana, M. 2006. Influence of developmental stage on sensitivity to ammonium nitrate of aquatic stages of amphibians. Environmental Toxicology and Chemistry, 25(1), 105-111.

33. Ortiz-Santaliestra, M.E., Fernández-Benéitez, M.J., \& Marco, A. 2012. Density effects on ammonium nitrate toxicity on amphibians. Survival, growth and cannibalism. Aquatic Toxicology, 110, 170-176.

34. PCN. 2016. National Framework Plan for MCPD. Sector plan "Sustainable agriculture and food" Morocco, 2016. (In French)

35. Polo-Cavia, N., Burraco, P., Gomez-Mestre, I., 2016. Low levels of chemical anthropogenic pollution may threaten amphibians by impairing predator recognition. Aquat. Toxicol. (N.Y.) 172, 30-35.

36. Randall, D.J., Tsui, T.K.N., 2002. Ammonia toxicity in fish. Mar. Pollut. Bull. 45, 17-23.

37. Ribeiro-Jr, J.W., Siqueira, T., Brejão, G.L., Zipkin, E.F., 2018. Effects of agriculture and topography on tropical amphibian species and communities. Ecol.
Appl. 28 (6), 1554-1564.

38. Rodier J. 2009. Analysis of natural water, wastewater, seawater, 9th Edition. Dunod Paris.

39. Salla, R.F., Gamero, F.U., Ribeiro, L.R.. et al. 2015. Cardiac adaptations of bullfrog tadpoles in response to chytrid infection. J. Exp. Zool. Part A Ecol. Genet. Physiol. 323, 487-496.

40. Scholefield D, Lord EI, Rodda HJE, Webb B. 1996. Estimating peak nitrate concentrations from annual nitrate loads. J. Hydrol. 186, 355-373.

41. Schmuck R, Geise W, Linsenmair KE. 1994. Lifecycle strategies and physiological adjustments of reedfrog tadpoles (Amphibia,Anura, Hyperoliidae) in relation to environmental conditions. Copeia 1994, 996-1007.

42. Sherkov, J.K., 1970. Morpho-physiological characterization of peripheral motor apparatus in Salamandra salamandra. J. Evol. Biochem. Physiol. 6, 467-469.

43. Sparling, D.W., Linder, G., Bishop, C., Krest, S., 2010. Ecotoxicology of Amphibians and Reptiles. SETAC/Taylor \& Francis, Boca Raton.

44. Wright, P.M., Wright, P.A., 1996. Nitrogen metabolism and excretion in bullfrog (Rana catesbeiana) tadpoles and adults exposed to elevated environmental ammonia levels. Physiol. Zool. 69, 1057-1078.

45. Yan, D., Jiang, X., Xu, S. et al. 2008. Quantitative structure-toxicity relationship study of lethal concentration to tadpole (Bufo vulgaris formosus) for organophosphorous pesticides. Chemosphere 71, 1809-1815.

46. Zhao, T., Wang, X., Wang, X. et al. 2019. Effects of urea on behavior and functional traits of Asiatic toad (Bufo gargarizans) tadpoles. Aquatic Ecology, 53(1), 9-19. 